\begin{tabular}{|c|c|c|c|}
\hline Article Info & RESEARCH ARTICLE & ARAŞTIRMA MAKALESİ & \\
\hline Title of Article & \multicolumn{2}{|c|}{$\begin{array}{c}\text { Evaluation Of Urban Open Spaces: The } \\
\text { Case of Karaköy }\end{array}$} & 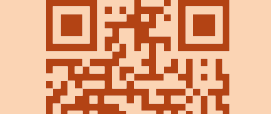 \\
\hline $\begin{array}{l}\text { Corresponding } \\
\text { Author }\end{array}$ & \multicolumn{2}{|c|}{$\begin{array}{l}\text { Shaylan OUDEH } \\
\text { İstanbul Teknik Üniversitesi, Mimarlık Fakültesi, Şehir ve Bölge Planlama Doktora } \\
\text { Programı Ögrencisi, oudeh19@,itu.edu.tr }\end{array}$} & 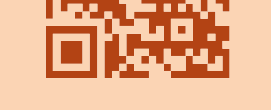 \\
\hline $\begin{array}{l}\text { Received Date } \\
\text { Accepted Date }\end{array}$ & \multicolumn{2}{|l|}{$\begin{array}{l}25.01 .2021 \\
25.03 .2021\end{array}$} & \\
\hline Author / Authors & $\begin{array}{l}\text { Y. Mim Shaylan OUDEH } \\
\text { Prof. Dr. Handan TÜRKOĞLU }\end{array}$ & $\begin{array}{l}\text { ORCID: 0000-0001-9121-9347 } \\
\text { ORCID: 0000-0002-1228-1239 }\end{array}$ & \\
\hline How to Cite & \multicolumn{2}{|c|}{$\begin{array}{l}\text { OUDEH, S. and TÜRKOĞLU, H. (2021). Kentsel Açık Alanların Değerlendirilmesi: } \\
\text { Karaköy Örneği, Kent Akademisi, Volume, 14, Issue 1, Pages, 29-45. }\end{array}$} & $\begin{array}{l}\text { Kent Akademisi } \\
\text { Uriban Acadeñy }\end{array}$ \\
\hline
\end{tabular}

\title{
Kentsel Açık Alanların Değerlendirilmesi: Karaköy Örneği
}

Y. Mim Shaylan OUDEH ${ }^{1}$ Prof. Dr. Handan TÜRKOĞLU ${ }^{2}$

\begin{abstract}
:
Urban open spaces are spaces where city dwellers have gathered and socialized throughout history. The role of urban open spaces, which are also regarded as public spaces, has changed in the current century according to globalization, privatization, real estate policies and urban transformation projects. Within the framework of this change, open spaces which are independently used by the residents are disappearing. In this study, the square placed at the Karaköy near the Galata Bridge, which has the potential to be used as an urban space but offers a limited spatial infrastructure for user activities, is evaluated within the framework of the public space literature supporting public life. In this context, the potential of the area to participate in the urban system as an urban open space was investigated using methods based on observations and interviews under the titles of attraction, accessibility, activities carried out in the area and place identity.
\end{abstract}

According to the observation and interview results, the area with a strong identity which is preferred by the users is far from meeting the requirements in terms of physical conditions. In general, the results reveal the use potential of the field as a public space on the one hand, and its limitations on the other.

KEYWORDS: Public Space, Public Life, Place Identity, Karaköy.

1 Istanbul Technical University, Graduate School of Science Engineering and Technology, Urban and Regional Planning PhD Programme, oudeh19@itu.edu.tr

2 Istanbul Technical University, Faculty of Architecture,Department of Urban and Regional Planning, turkoglu@itu.edu.tr 


\section{ÖZ:}

Kentsel açık alanlar tarih boyunca kentte yaşayanların bir araya geldiği ve sosyalleştiği alanlar olmuştur. Kamusal alanlar olarak da kabul edilen kentsel açık alanların rolü, içinde bulunduğumuz yüzyılda küreselleşme, özelleştirme, gayrimenkul politikaları ve kentsel dönüşüm projeleri ile değişime uğramıştır. Bu çalışmada, kentsel alan olarak kullanma potansiyeli olan ancak kullanıcı aktiviteleri için kısıtlı bir mekansal altyapı sunan Galata Köprüsünün Karaköy ayağındaki meydan, kamusal mekan ve yaşamı konu alan literatür çerçevesinde değerlendirilmektedir. Bu kapsamda söz konusu alanın kamusal açık alan olarak kentsel sisteme katılma potansiyeli, alanın fiziksel özellikler ve çekiciliği, erişilebilirlik, kullanım, aktivite türleri ve yer kimliği başlıklarında gözlem ve görüşme tekniğiyle yapılan analizlere dayalı olarak değerlendirilmiştir. Gözlem ve görüşme sonuçlarına göre kuvvetli kimliği olan ve kullanıcılarca tercih edilen alan fiziksel koşulları açısından gereksinimleri karşılamaktan uzaktır. Genel olarak sonuçlar alanın, bir yandan kamusal alan olarak kullanım potansiyelini diğer yandan kısıtlarını ortaya koymaktadır.

ANAHTAR KELIMELER: Kamusal Alan, Kamusal Yaşam, Yer Kimliği, Karaköy

\section{“Kentsel Açık Alanların Değerlendirilmesi: Karaköy Örneği”"}

\section{GİRIş:}

Bu çalışmanın temel amacı, İstanbul'un Karaköy sahil bölgesinde yer alan ve kamusal mekan olarak ayrılmadığı halde kamusal alan potansiyeli bulunan alanın kamusal alan niteliğini saptamak ve kentsel açık alan sistemine kazandırılmasını sağlamaktır. Çalışmada, alanın kentsel açık alan olarak fiziksel özellikleri ve çekiciliği, erişilebilirliği, alanda gerçekleşen kullanım ve aktiviteler ve yer kimliği parametreleri değerlendirilmektedir.

Haliç'in girişinde yer alan Karaköy Limanı tarihsel gelişimi ve fiziksel yapısı nedeniyle önemli bir dönüşüm alanıdır. Farklı dönemler, mimari tarzlar ve sosyo-demografik yapıya tanık olan Karaköy, aynı zamanda eski ve yeni, Doğu ve Batı, iş ve eğlence, yerli halk ve turistler arasındaki diyalektiği farklılaştırmak ve bu farklılıklar arasındaki ilişkiler, kentsel sosyal üretimler için dinamik bir zemin oluşturmaktadır. Çalışma alanı olarak seçilen alan Karaköy'de, Galata Köprüsü'nün kuzeybatı bölgesinde bulunmakta, kuzeyinde Fermeneciler Caddesi, balık pazarı, balık lokantaları ve Turyol Feribot İstasyonu yer almaktadır (Şekil 1). 


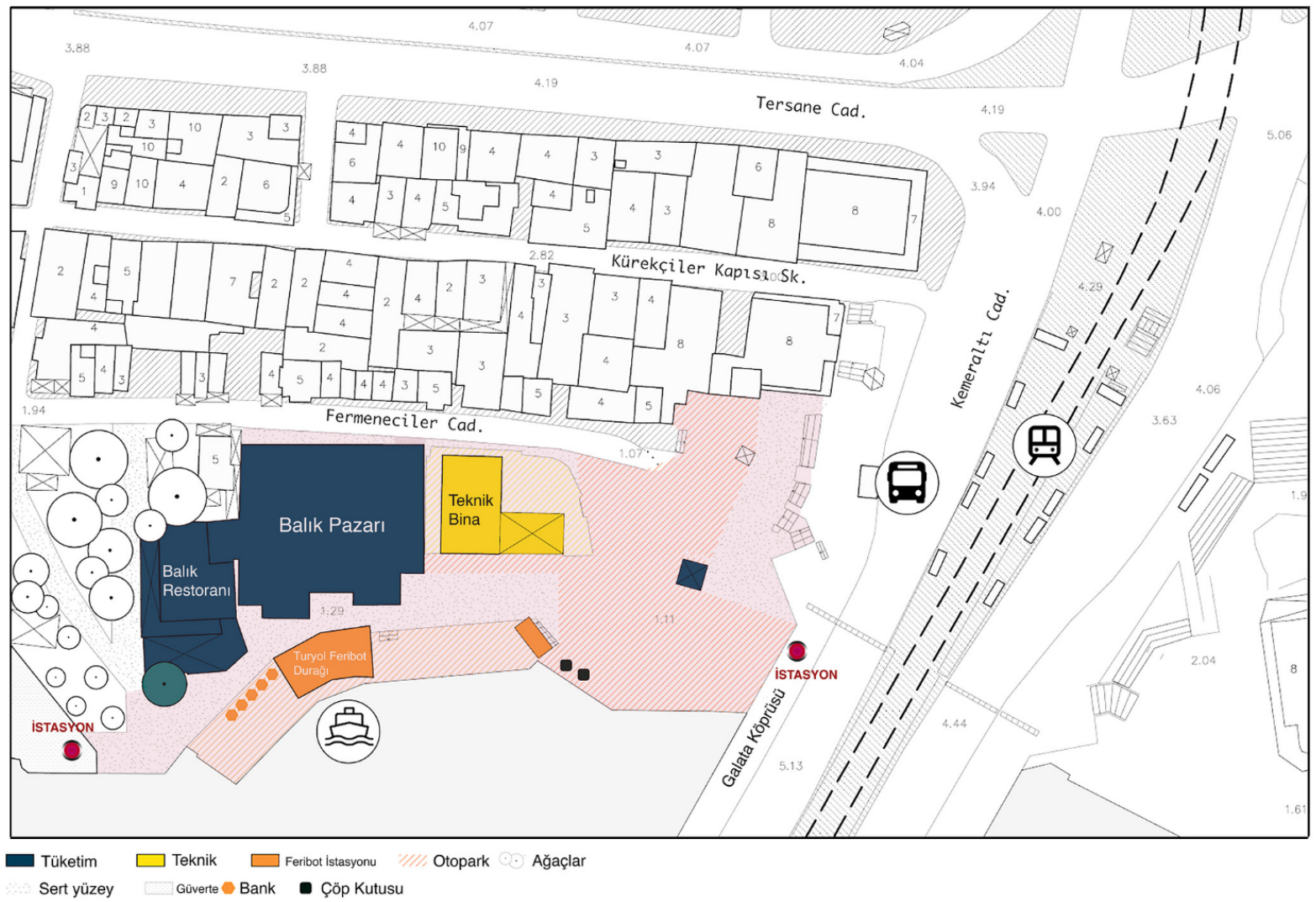

Şekil 1. Çalışma Alanı

Alanın kamusal alan olarak değerlendirilmesinde kamusal mekan literatüründen derlenen ve aşağıda belirtilen temel sorular araştırılmıştır.

- $\quad$ Kamusal yaşam, ne tür aktivitelerle tanımlanabilir? Bu aktiviteler zorunlu, isteğe bağlı veya sosyal faaliyetler olarak sınıflandırılabilir mi? Alanda gayri resmi aktiviteler gözlenmekte midir?

- Kullanıcılar alanı çekicilik ve erişilebilirlik açısından nasıl değerlendirmektedir?

- Alanda yer kimliği nasıl tanımlanabilir? Alandaki mevcut faaliyetler yer kimliğini engellemekte veya desteklemekte midir?

- $\quad$ Alanın kamusal alan olarak kentsel açık alan sistemine katılması mümkün müdür?

\section{Kamusal Mekan, Kamusal Yaşam ve Yer Kimliği}

Shakespeare'e göre "şehir halkttr". Kentler bilindiği gibi fiziksel biçimleri ve sosyal ortamları arasındaki ilişki çerçevesinde şekillenir ve içinde yaşayan toplumların kültür ve davranışlarını yansıtır.

Çağlar boyunca buluşma ve deneyim alanı rolünü üstlenen mekanlar olarak tanımlanan kentsel kamusal alanlar, literatürde geniş bir yere sahiptir. 20. yüzyılın teorisyenleri kentsel kamusal alan ve kentsel yaşam kalitesi ilişkisi üzerine çeşitli görüşler ortaya atmışlardır. Lynch (1960) mekanın okunabilirliğini analiz etmiş, kentin kamusal 
mekanlarını odak ve referans öğeleri olarak tanımlamıștır. Jacobs (1961) kentsel açık alanlar ile sosyal ilişkilerin etkileşiminden bahsetmiş, otomobilin kentsel kamusal alanları tahrip ettiğini öne sürmüştür. Simmel (1950) toplumsal yapının oluşumuna etki eden mekanlara, Lefebvre (1971) kamusal mekandaki günlük yaşamın önemine dikkat çekmiştir. Sennett (1999) kent kullanıcılarını mekan kimliğinin bir yaratıcısı olarak görmüş, Bourdieu (1984) birey ile sosyal yapı arasındaki ilişkinin ve kültürel normların anlaşılması konusunu ele almıştır.

Bu bağlamda, kentsel kamusal alanlar sadece sosyal bir ürün değil, aynı zamanda iyi işleyen bir toplum için bir ön koşuldur. Lefebvre (1991) bunu şöyle açılar: "Yaşamı değiştir! Toplumu değiştir! Bu ilkeler, uygun bir alan yaratmadan tamamen anlamlarını yitirir" (Lefebvre,1991, s. 59).

Jacobs (1961) şehirlerde, görme duyusunun gözlem için anahtar olduğu, ancak bunun diğer duyularımızı kapatmak anlamına gelmediğini vurgulamıştır. Bu yaklaşım dikkatimizi çeken nesnelere odaklanmak ve her gün bilinçsizce geçtĭgimiz çevreyi fark etmek anlamına gelmektedir.

Kentsel mekanın biçimlendirilmesiyle ortaya çıkan yapılaşmış çevre, toplumun gündelik yaşam pratikleri ile de ilişkilidir. Lilja (1995) kimliği, etik, mekan ve zaman boyutunda; günlük yaşamda anlam arayışının bir sonucu olarak ortaya çıkan ve geçmiş ile şimdiki zaman ve gelecek arasında bir bağlantının yanı sıra kişi ve fiziksel çevre (yapılaşmış ve doğal) arasındaki bağlantıyı kuran bir unsur olarak tanımlar. Lilja’ya göre kimlik, günlük olaylarla bağlantılı olarak şekillenir ve fiziksel çevrenin kullanıcıları ile kurduğu ilişkilere bir 'anlam yaratma' süreciyle sonuçlanır.

Lynch (1960) ise yere bağlı tanınabilir, akılda kalıcı kimliğin gerekliliği ve kentsel mekanın fiziksel organizasyonu ile mekanın okunabilirliği arasında bütünleşme ve biçim, işlev ve sosyal yaşamın uyumlaştırılması (mekanın anlamı) olduğunu vurgular.

"Her şeyden önce, eğer çevre gözle görülür ve net bir biçimde düzenlenir ve tanımlanırsa, o zaman kullanıcı onu kendi anlamları ve bağlantılart ile ilişkilendirebilir. Işste o zaman gerçek bir yerden bahsedebiliriz." (Lynch, 1960: 92)

Lynch (1981) kentin doğal, sosyal ve yapılı çevre arasındaki ilişkisi onu diğerlerinden farklılaştırdığını ve bu farklılık onun kimliğini oluşturduğunu söyler. Doğal çevreye dayalı kimlik öğeleri, doğal olaylar iken, sosyal çevreye bağlı kimlik, içinde bulundukları kültürel yapı ile bütünleştir. Yapılı çevreye dayalı kimlik öğeleri ise, konumları, kullanım türleri ve anlamları üzerinden değerlendirilir (Ocakçı, 1993, 1994, 1995; Suher vd., 2004, s. 27)

Hauge (2004)'a göre yer, anlam ve duygu terimlerinden ilham alınmış alan olarak tanımlanmaktadır. Mekanlar ise temel olarak görsel, ancak işitsel ve dokunsal deneyimler ve bunların yorumlanması olarak bellek ve duyusal deneyimlerin karışımını da içerirler. Bu tanım çerçevesinde mekan anlam, duygular ve hikayelerle tanımlanan coğrafi bir alan olarak anlaşılabilir. Anlatılar ve yorumlar, yerin kimliğini ortaya çıkarır. Hauge (2004) hangi bileşenlerin kimliğe şekil verdiğini anlamak için Amundsen'in çalışmasından bahseder. Amundsen, yer kimliğini yakalamak için yaygın olarak kullanılan dört ana bileşenden bahseder (Hauge, 2004, s. 3-17):

- $\quad$ Yeri diğerlerinden ayıran mekansal nitelikler: Konum, altyapı, iletişim ve mimari

- $\quad$ Yeri diğerlerinden ayıran özellikler ve nitelikler: Değerler, gelenekler, fiziksel görünüm

- Sosyal koşullar ve bölge sakinleri arasındaki sosyal ilişkiler

- $\quad$ Birleştirici bir unsur olarak kültür ve/veya tarih: Kültür ve tarih kullanıcıları diğerlerinden ayırır.

Bu çerçevede, yer kimliği, diğer insanlar, diğer yerler ve o yer için diğer kimliklerle ilişkili olarak oluşturulmuş bir olgu olarak karşımıza çıkmaktadır.

Bir çok grup kamusal alanlarda mekan kalitesinin ölçülebilmesi için farklı parametreler belirlemişlerdir. Whyte (2000) tarafından oluşturulan parametrelere dayalı olarak geliştirilen ve PPS (Project For Public Spaces) yaklaşımı başarılı bir 
kamusal alanın dört nitelik sunması gerekliliği vurgulamaktadır. Bunlar; erişilebilirlik, konfor ve imaj, aktivite ve sosyal yaşamdır.

Öte yandan yer kimliği, konum, tarih, tasarım, mimari veya sanat yoluyla yere anlam yükleyen çok önemli bir faktör olarak ortaya atılmıştır (Gehl ve B. Svarre, 2013). Gehl (1987)'e göre, fiziksel özellikler, cinsiyet, yaş, finansal kaynaklar, kültür ve diğer birçok faktör kamusal alanı nasıl kullandığımızı belirlemektedir. Gehl (1987) ayrıca kamusal alandaki aktiviteleri zorunlu, isteğe bağlı ve sosyal aktiviteler olmak üzere üç kategoriye ayırmaktadır. Zorunlu aktiviteler her türlü hava koşullarında gerçekleşmesi gereken okula veya işe gitmek, alışveriş yapmak, otobüs beklemek gibi kamusal alanın fiziksel kalitesinden bağımsız olarak gerçekleşen günlük aktiviteleri, isteğe bağlı aktiviteler ise güzel bir havada yürüyüşe çıkmak, bankta oturup güneşlenmek, açık havada yemek yemek, kitap okumak gibi rekreasyonel aktiviteleri kapsar. Bu aktiviteler, kentsel açık alanın fiziksel kalitesi ile yakından ilgilidir. Öte yandan isteğe bağlı aktiviteler birden fazla kişiyi kapsadığında örneğin çocukların oyun oynaması, selamlaşmak, sohbet etmek gibi aktiviteler sosyal aktivite grubuna girer. Sosyal aktiviteler veya sosyal etkinlikler ancak mekanın fiziksel ve sosyal kalitesinin olumlu olarak algılandığı durumlarda gerçekleşmektedir (PPS, 2008).

Öte yandan kamusal alanlarda pek çok örnekte ortaya çıkan kullanıcıların planlanmış aktivite dışında geliştirdikleri seyyar satıcılar, dükkan önü oturma grupları gibi gayrı resmi aktivitelerle yeni bir yaşam alanı üretildiği de gözlenmektedir (Lefebvre 1991). 'Resmi' faaliyetler standart, norm, kural haline gelen asimile edilmiş, belirli formları, öğeleri veya prosedürleri kapsayan faaliyetleri ifade ederken, 'gayri resmi' faaliyetlerin tanımı, genellikle resmi süreçlerin veya planlanmış durumların dışında gerçekleşmektedir. Bu terimler arasında, karşııtlık olmayan ince bir ilişki vardır. Resmi olan, kesin kurallar ve yönergeler sağlarken, gayri resmi olanlar kendi kendini örgütleyen aktiviteleri kapsamaktadır (Lutzoni, 2016).

\section{1. Çalışma Alanı Olarak Karaköy}

Aslan (2011)'a göre İstanbul, köprülerle daha iyi okunabilen bir şehirdir. Galata köprüsünün ayağında yer alan Karaköy, İstanbul'un en eski ve en tarihi semtlerinden biri ve günümüzde şehirlerarası ve uluslararası yolcu trafiği için önemli bir ulaşım merkezidir. Galata Köprüsü aracılığıyla Eminönü, Galata ve Beyoğlu semtlerini birbirine bağlayan Karaköy, Bizans döneminden beri bir liman alanı olarak görev yapmıştır.

Bölgenin ve çevresinin demografik yapısına bakıldığında, tarihsel süreçteki değişiklikler, bölgede yaşayanların sosyodemografik yapısında değişime neden olmuş, Yunanlılar, Latinler, Yahudiler, Ermeniler ve Türklerin 11. yüzyıldan beri bölgeye yerleştikleri görülmüştür (Freely, 2005). Çeşitli etnik ve dini grupların yanı sıra, Akdeniz ve Ortadoğu'nun her yerinden gelen denizci ve tüccar nüfusun da bu bölgede yerleştiği görülmektedir.

Modernleşme sürecinde Galata ve çevresinin fiziksel ve sosyal yapısı Karaköy'ün kimliğinde önemli rol oynamıştır (Tekeli, 1996). 19. yüzyılın ikinci yarısından sonra Karaköy, ticari bir alan olarak özellikle Bankalar Caddesinde yer alan ticari binalar, ofisler, depolar, mağazalar, borsa ve bankacılar ile Osmanlı ekonomisinde önemli bir rol oynamıştır (Akın, 2011). Karaköy'ün kozmopolit yapısı, farklı dinlere ait ibadethanelerin, kültür merkezlerinin, ortaya çıkmasına neden olmuştur. Karaköy karakteristik dokusu ile 21. yüzyılda bir turizm çekim merkezi haline gelmiştir.

Galata Köprüsü, Karaköy'ü hızlı tramvay hattı ile (Zeytinburnu- Kabataş) Eski İstanbul'a, Tünel adı verilen yeraltı füniküler ise, 1876'dan beri Karaköy'u İstiklal Caddesi'ne bağlar. Karaköy iskelesinden de Kadıköy'e yolcu akışı vardır. Böylece Karaköy, yüzyıllardır aktif bir iş ve ulaşım merkezi olarak İstanbul'un önemli bir dügümm noktasıdır. Ayrıca Galata Köprüsünün altında bulunan küçük balık restoranları ve tüm alana yayılan kafeler ile yerli ve yabancı turistler için cazip bir alandır. 
Karaköy'ün 'Perșembe Pazarı' bölgesinde yer alan Balık Pazarı, kullanıma açık alanlardan biri olmuştur (Şekil 2). Balıkçı tezgahları, balık satıııları, çay bahçeleri ve restoranları 2015 yılında Belediye tarafından yetkisiz ve yasadışı işletmeler olarak yıkıldığı görülmektedir (Hürriyet, 2015). Yeni balık pazarı Haziran 2015'te yeni binasında 25 işyeri ile hizmete açılmıştır. Yerli ve yabancı turistleri cezbeden bu alan deniz ürünleri satışı ile tanınmaktadır (Şekil 3).

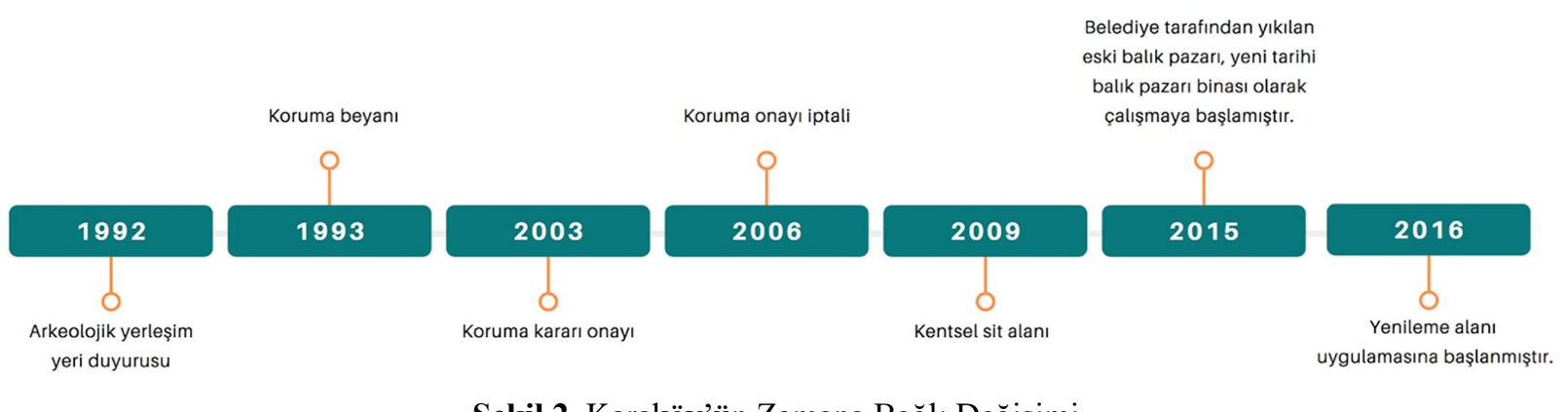

Şekil 2. Karaköy’ün Zamana Bağlı Değişimi

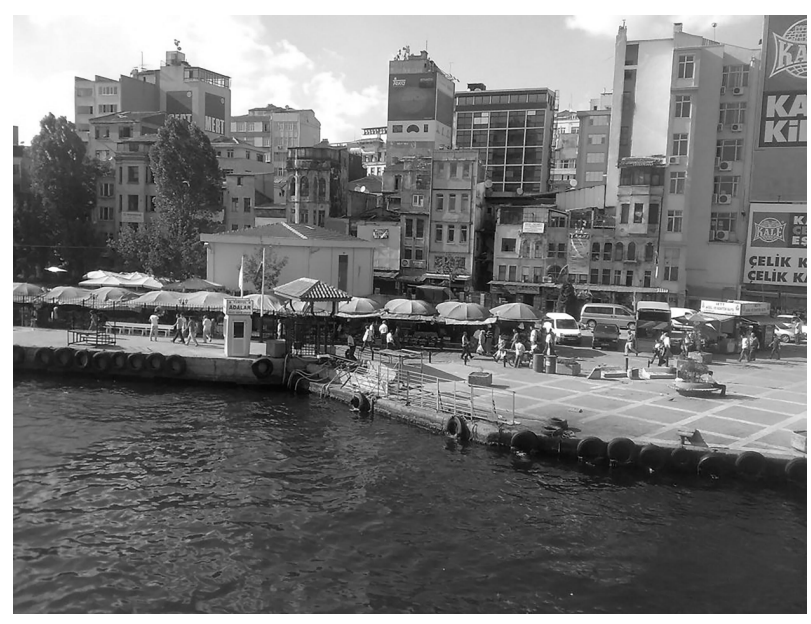

(Eski)

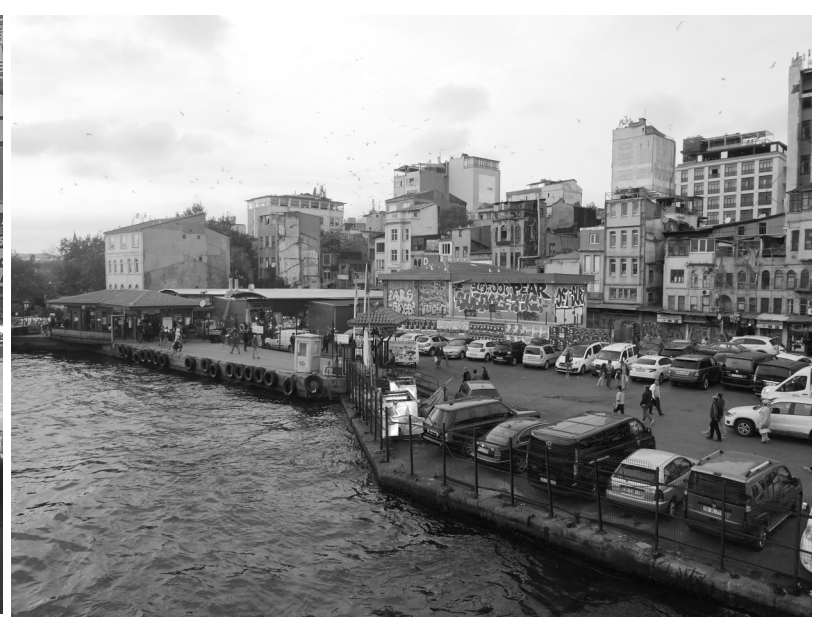

(Yeni)

Şekil 3. Çalışma Alanının Eski ve Yeni Durumu

(Kaynak: https://mapio.net/pic/p-14692259/, 21 Ocak 2020 tarihinde erişildi.)

\section{Yöntem}

Çalışma alanını değerlendirmek amacıyla sahada gözlem, haritalama tekniği, yüz yüze görüşme, video ve fotoğraf teknikleri kullanılmıştır. Sahada iki 'gözlem istasyonu' seçilerek her istasyonda 15 dakikalık gözlem ve kayıt yapılmıştır.

Çalışma alanında ilk aşamada Gehl (1987)'in literatürde vurguladığı zorunlu, isteğe bağlı ve sosyal aktiviteler saptanmış, aktiviteler gruplandırılmıştır. Alandaki hareketlilik, yürüme, bisiklete binme, bebek arabası veya tekerlekli sandalye kullanma gibi, gözlemsel olarak aktiviteler izlenmiştir. Gözlemler hafta içi sabahları (08.30-10.30), öğlen 
(11.30-13.30) ve akşamları (17.00-19.00), hafta sonu ise (14.00-16.00) dört aşamada gerçekleșmiştir. Gözlemler daha sonra Lynch (1960) ve Appleyard (1981) tarafından da kullanılan davranış haritaları ile görselleştirilmiştir. Bilindiği gibi Lynch (1960) ve Appleyard araştırmalarında kullanıcıların algılarına, deneyimlerine ve davranışlarına dayanarak şehirlerin fiziksel özelliklerini değerlendirmektedir.

Çalışmada gerçekleştirilen yüz yüze görüşmeler, kullanıcıların araştırılan alan hakkında olumlu veya olumsuz yönleri, alanın kendilerine ne anlam ifade ettiği ve onları farklı saatlerde alana getiren nedenleri anlamak, alanda hangi aktiviteleri yaptıklarını öğrenmek için kullanılmıştır. Yüz yüze görüşmeler civarda yaşayan veya ziyarete gelmiş kullanıcıları, alanda çalışan işçileri, dükkanlarda çalışan kişiler arasından seçilen kişileri kapsamaktadır.

Araştırma kapsamında kişilere aşağıda belirtilen sorular yöneltilmiştir:

\section{Kullanım ve Aktiviteler (Zorunlu, isteğe bağlı ve sosyal aktiviteler)}

1. Bu alanı ne sıklıkla ziyaret ediyorsunuz

2. Bugün sizi bu alana getiren nedir? Transit kullanıcı iseniz nereye gidiyorsunuz?

3. Bugün burada ne kadar zaman geçirmeyi planlıyorsunuz?

\section{Alanın Fiziksel Özellikleri ve Çekiciliği}

1. Bu alanın sizi cezbeden özellikleri nelerdir?

2. $\quad \mathrm{Bu}$ alanda sizi rahatsiz eden nelerdir?

\section{Yer Kimliği}

1. Ziyaretçi misiniz, yoksa alanda çalışıyor musunuz?

2. Bu alan hakkında ne düşünüyorsunuz? Sizin için bir anlam ifade ediyor mu?

3. Bu alanla ilişkinizi en iyi nasıl tanımlarsınız?

4. Bu alanı tanımlamak için hangi kelimeleri kullanırsınız?

\section{Veri Analizi}

Gözlem sonuçları erişilebilirlik, kullanım ve aktiviteler, alanın fiziksel özellikleri başlıklarında ele alınmaktadır.

Alanın Fiziksel Özellikleri: Alanda bulunan binalar çoğunlukla boş veya harabe durumunda olup kullanılır durumda olanlar ise balık pazarı, restoran ve dükkan olarak kullanılmaktadır. Kiosk ise insanların atıştırmalık veya içecek satın alabileceği bir buluşma noktası olarak çalışmaktadır. Balık pazarı, restoranlar, sahil şeridi ve deniz manzarası alanı cazip kılan unsurlar olarak öne çıkmaktadır. Alanın daha çok bir ulaşım noktası olarak kullanılması sonucu kullanım yoğunluğu özellikle sabah ve akşam saatlerinde artmaktadır. Alandaki oturma ve dinlenme alanları yetersiz olup, yaya yolları, alanın otopark olarak da kullanılması ile kesintiye uğramaktadır. Kirliliğinin yüksek olduğu bu alanda ayrıca bitkilendirmenin ve gölge alanların yetersiz oluşu dikkat çekmektedir (Şekil 4). 


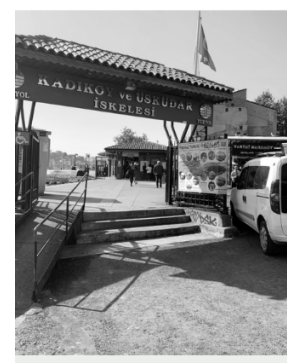

(Turyol) Durağı

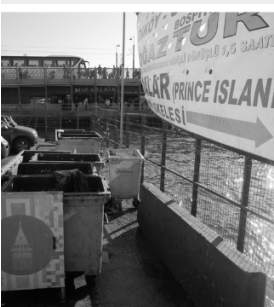

Çevre Kirliliği

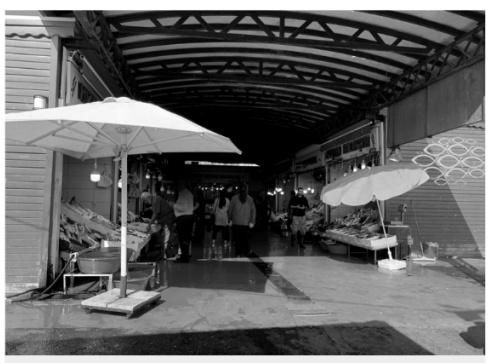

Balık Pazarı

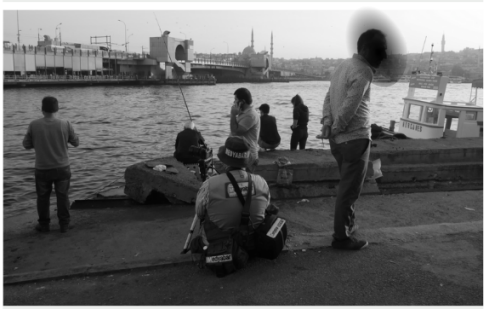

Deniz Manzarası

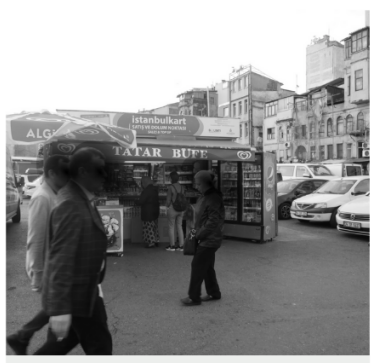

Kiosk Büfe

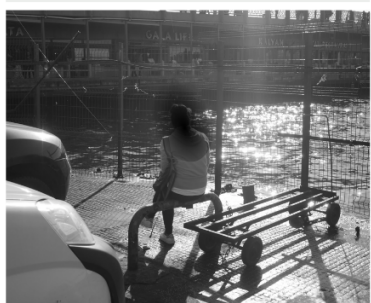

Oturma Alanlarının Yetersizliği

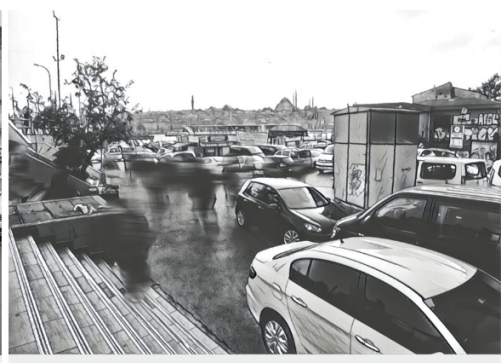

Park Edilmiş Araç Trafiği - Belirsiz Yaya Ağı

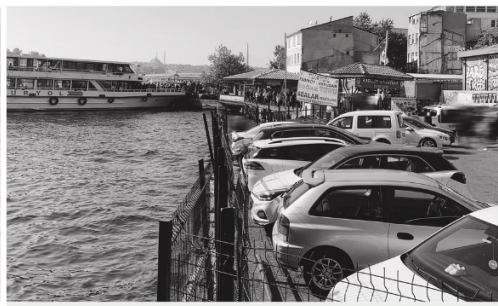

Manzaranın Kesintiye Uğramas

Şekil 4. Alanın Fiziksel Özellikleri

Erişilebilirlik: Karaköy bölgesi karayolu, demiryolu ve denizyolu ulaşım sistemlerinin kesişme noktasında bulunmaktadır. Toplu taşıma imkanları çeşitlidir. Bölgedeki en önemli araç yolu olan Tersane Caddesi, Boğaz'a paralel sahil yolunun devamı olarak Galata ile Atatürk köprüleri arasındaki bağlantıyı sağlamaktadır. Haliç metro istasyonu, tünel, iskeleler bölgeyi önemli bir odak noktası haline getirmektedir. Kullanıcıların çoğunun sokak seviyesinde feribot terminaline doğru hareket ettiği görülmektedir. Feribot istasyonuna giden rampalar tekerlekli sandalyeler ve bisikletlerin erişimini sağlamaktadır. Park edilmiş arabalar feribot terminaline ve balık restoranına giden yaya yolunu ve sahile ulaşımı engellemektedir. Öte yandan Kemeraltı Caddesi'nden ve Tünel çıkışından alana ulaşmak ancak çeşitli düzeylerde bulunan merdivenler ile mümkündür (Şekil 5). Erişilebilirlik açısından merkezi bir konuma sahip olan 
alanda iç dolaşım rampalar kullanılarak tekerlekli sandalye, bisiklet, bebek arabası içinde erişilebilir kılınmıştır. Bununla birlikte alanda yaya dolaşımı otopark nedeniyle sınırlandırılmıştır.

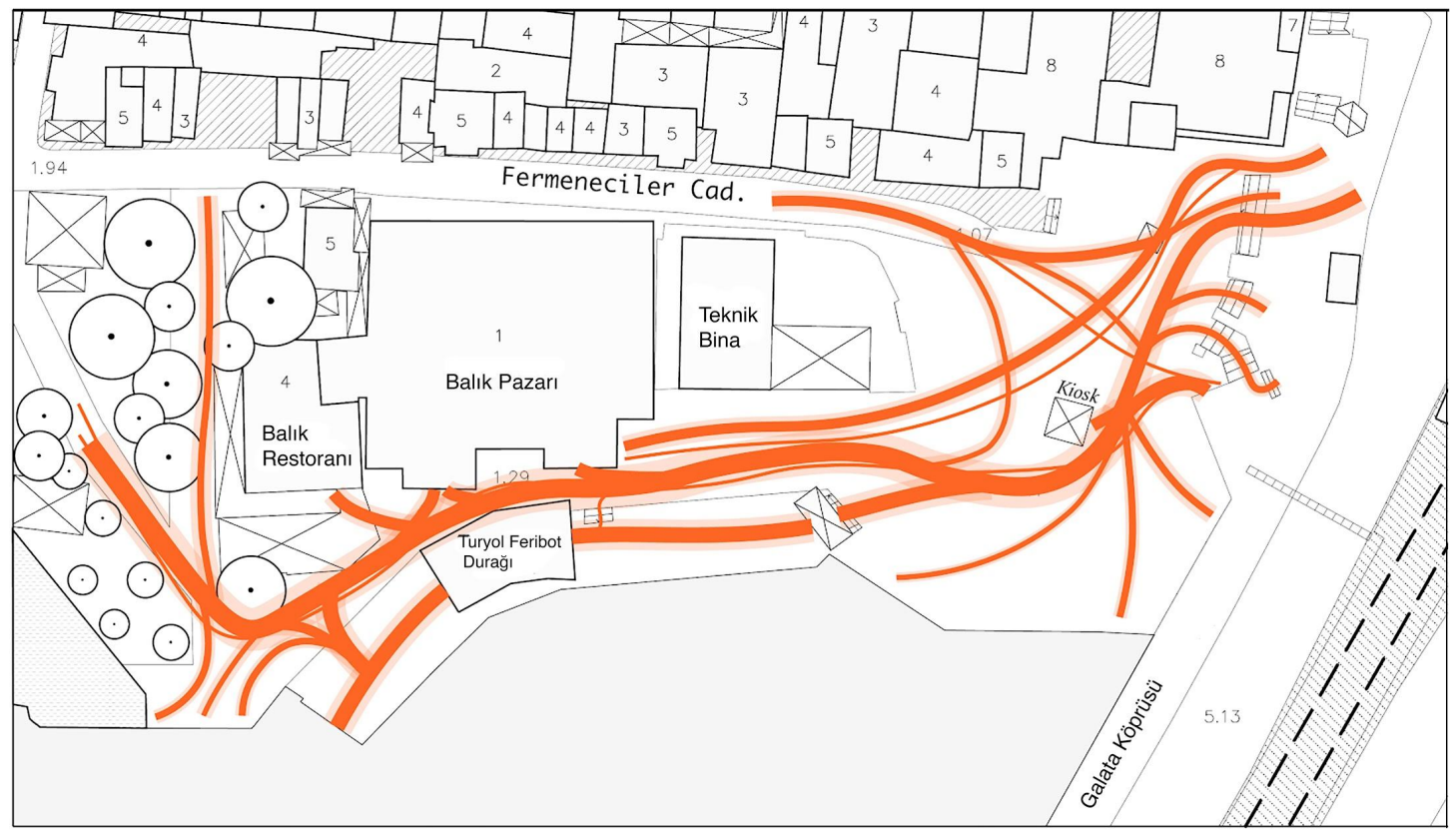

Şekil 5. Erişilebilirlik Analizi

Kullanım ve Aktiviteler: Alanda haftanın ve günün farklı saatlerinde yapılan gözlemlerin sonuçları manzaraya bakma, fotoğraf çekme, balık tutma, oturma, yemek yeme, ürün satışı ve dağıtımı, atık toplama gibi aktivitelere rastlanmıştır. Aktiviteler resmi veya gayri resmi ve zorunlu, isteğe bağlı ve sosyal aktiviteler olarak ele alınmıştır.

Alanda hafta içi sabah saatlerinde gerçekleşen sınırlı aktivitelerin daha çok iskeleye gidenler ve işçilerin atık toplaması, yine hafta içi öğle saatlerinde belirtilen tüm aktivitelerin gerçekleştiği görülmektedir (Şekil 6 ve 7). Deniz ulaşımını kullanan yolcuların bilet aldıktan sonra çitle çevrili alandaki oturma olanağını kullanarak veya ayakta durarak bekledikleri, diğer kullanıcıların ise istasyon binasının doğusundaki bölgede ayakta durarak deniz manzarasını seyrettikleri gözlenmiştir. Hafta İçi akşamları en kalabalık saatler olarak gözlenmektedir (Şekil 8). Özellikle iskeleyi kullanan yolcuların alanı kullandıkları görülmektedir. Bu yoğun kullanıma park etmiş arabalar ve yoğun trafik sınırlama getirmektedir. 


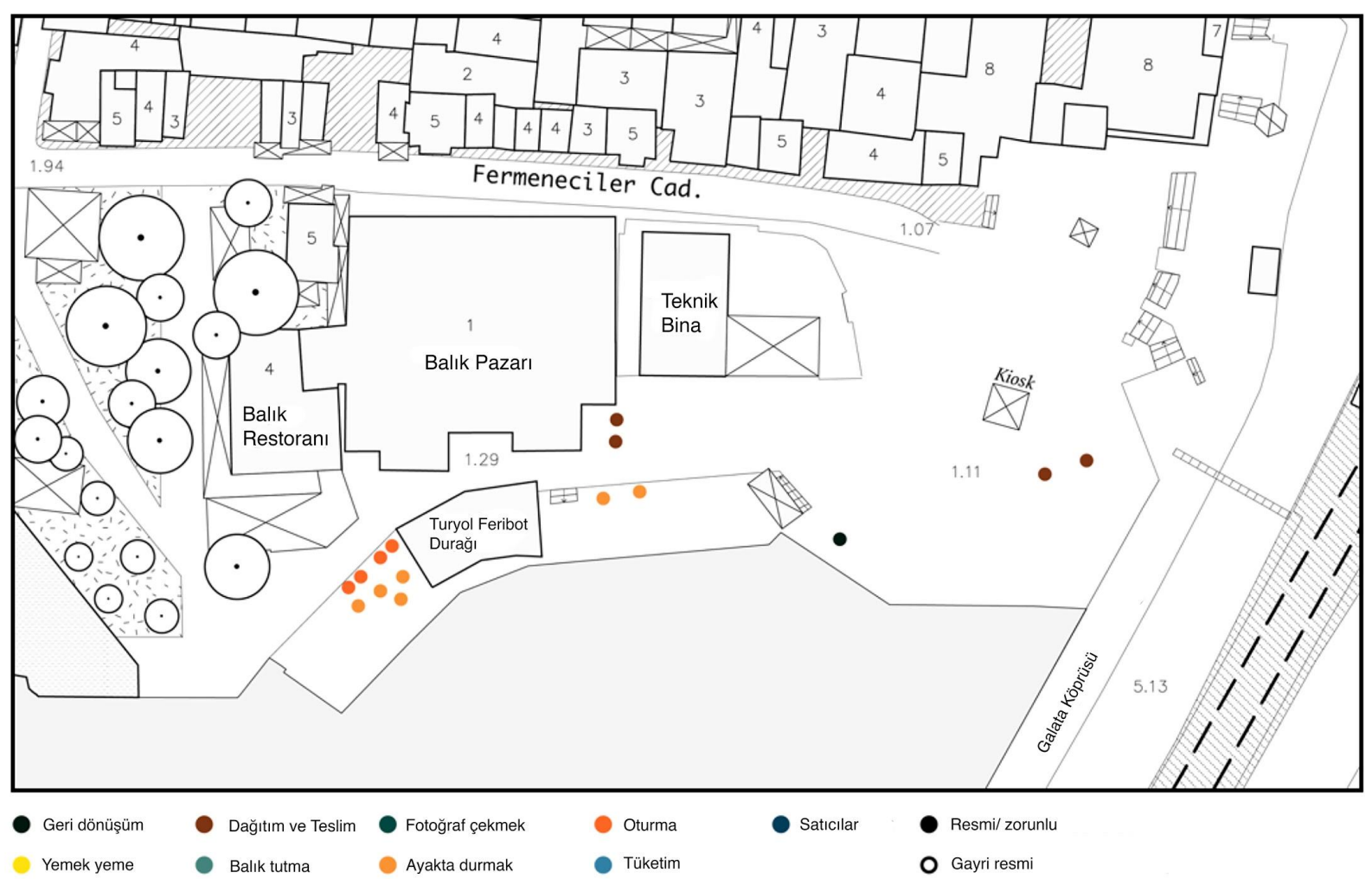

Şekil 6. Sabah Saatlerinde Yapılan Gözlemler 


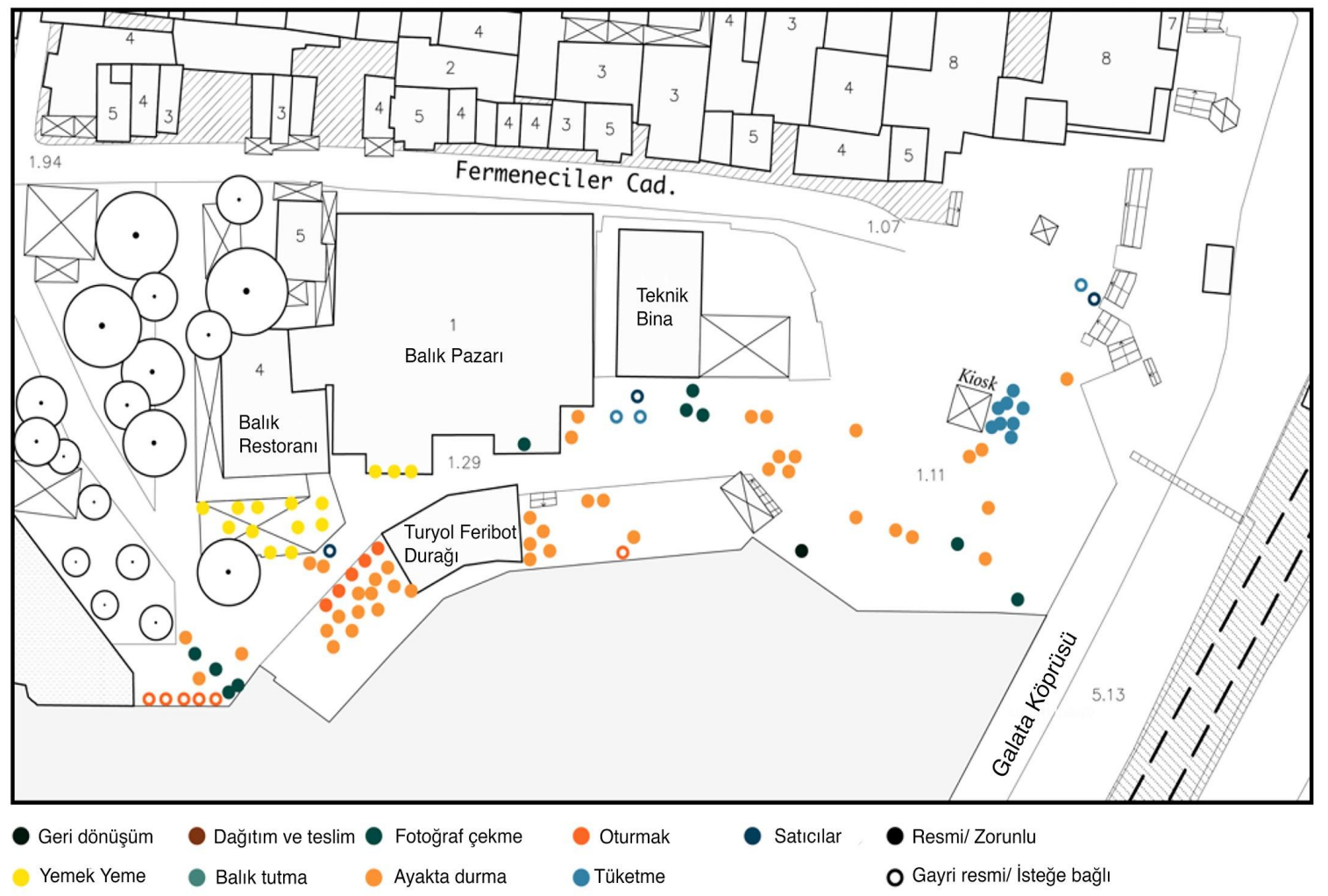

Şekil 7. Öğle Saatlerinde Yapılan Gözlemler 


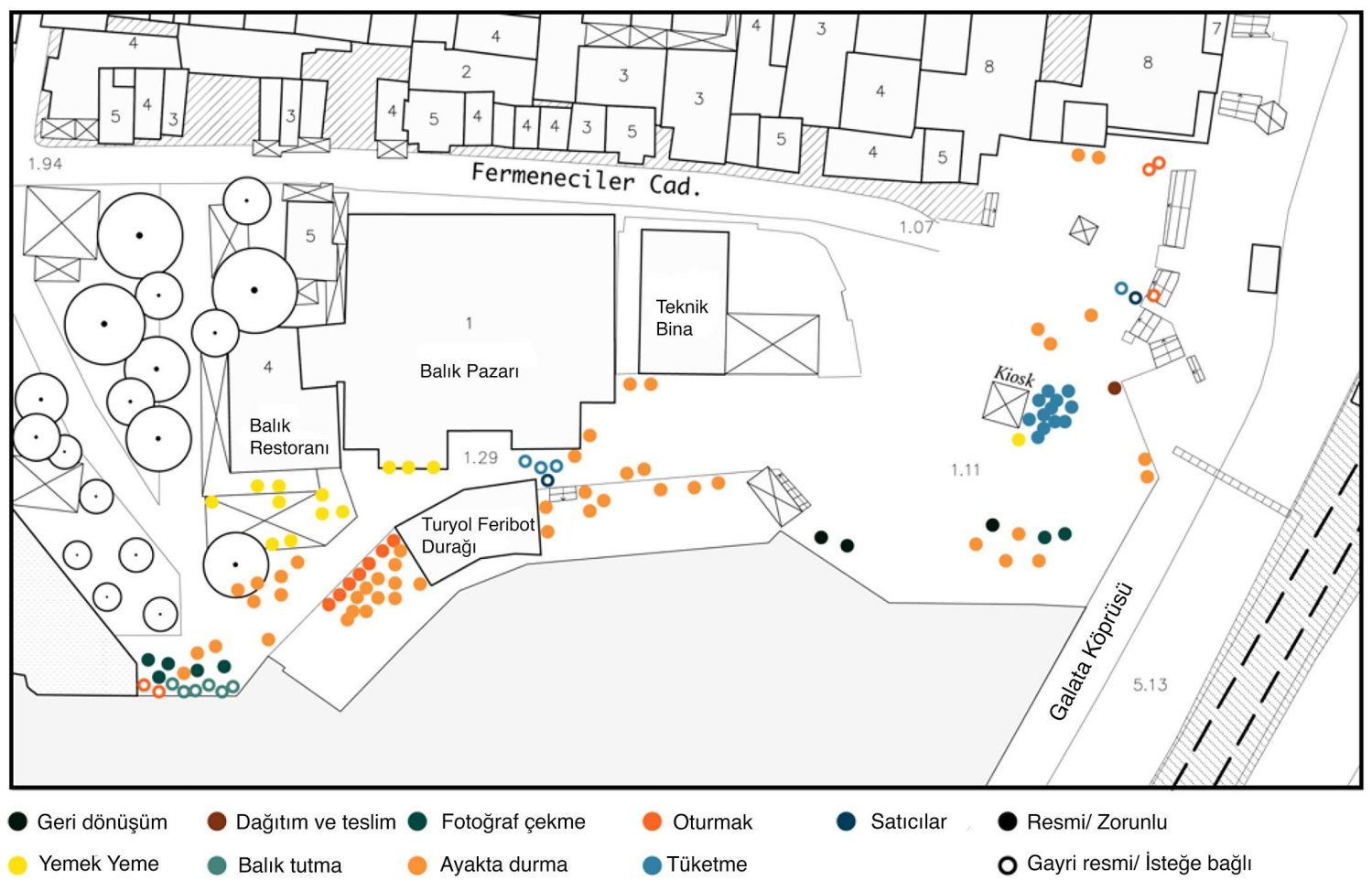

Şekil 8. Akşam Saatlerinde Yapılan Gözlemler

Hafta sonu boyunca alanın oldukça sakin olduğu gözlenmektedir. Atık toplama işçileri hafta sonu boyunca görevlerini yapmışlardır. Kullanıcılar tarafından Kemeraltı Caddesi tarafındaki merdivenler ve feribot iskelesi çevresindeki merdivenlerin oturma alanı olarak kullanıldığı görülmektedir (Şekil 9). 


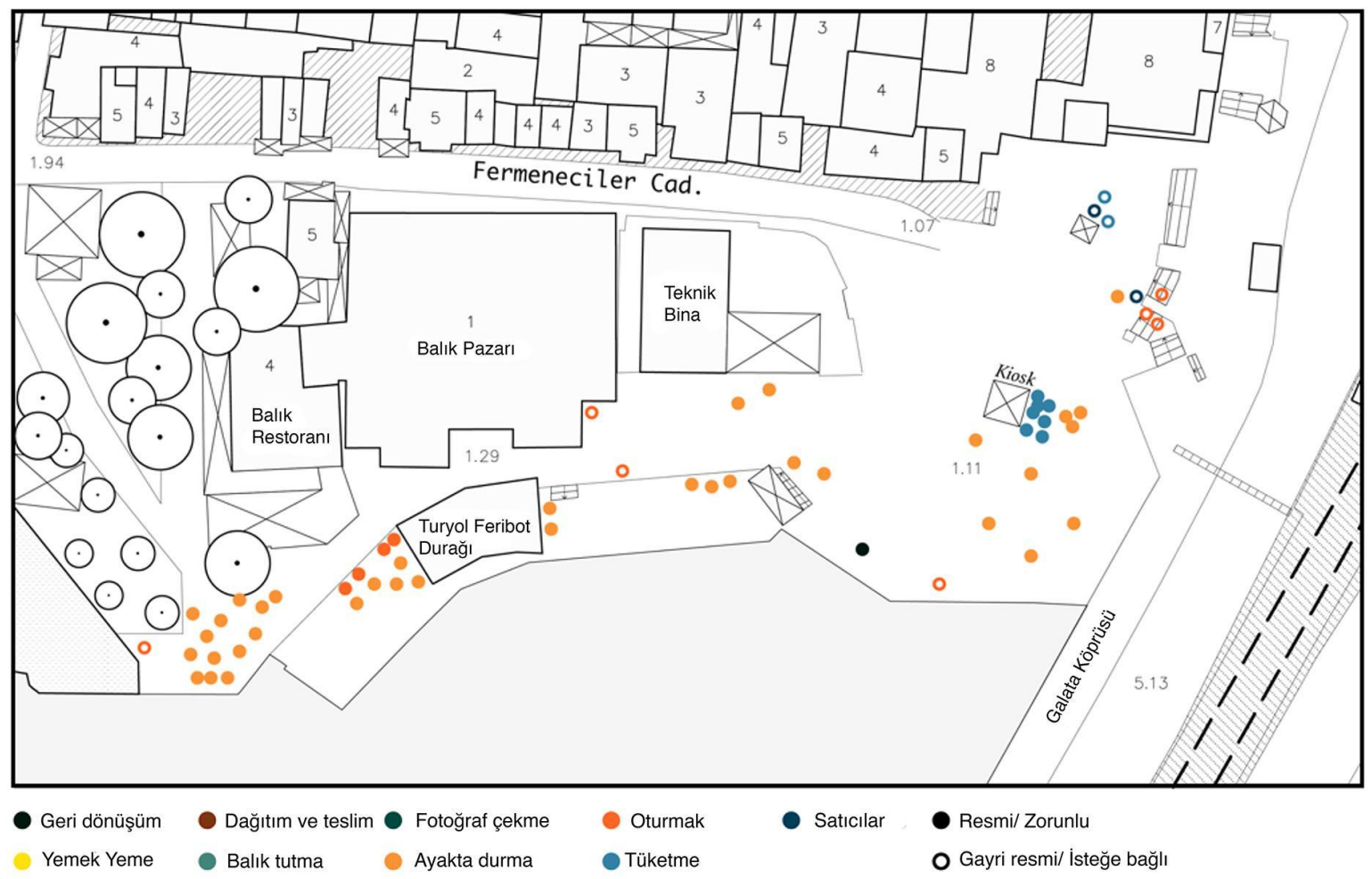

Şekil 9. Hafta Sonu Saatlerinde Yapılan Gözlemler

Aktivitelerin çoğunun işe geliş gidiş için feribot iskelesini ve diğer toplu taşıma araçlarını kullanan kullanıcılar tarafından gerçekleştirildiği ancak iskeleyi kullanmadan önce ve iskeleye vardıktan sonra kullanıcıların isteğe bağlı aktiviteler de gerçekleştirdiklerini göstermektedir.

Sınırlı sayıda da olsa isteğe bağlı aktiviteler arasında kiosk dan ve sokak satıcılarından alışveriş yapmak, ayakta veya oturarak beklemek ve fotoğraf çekmek gibi aktiviteler sayılabilir. Alanda saptanan sosyal aktiviteler arasında ise balık tutmak, restoranın açık alanında yemek yemek gibi aktivitelere rastlanmaktadır (Şekil 10).

Öte yandan görüşme sonuçları farklı zamanda yapılan 23 görüşmenin sonuçlarına dayanmaktadır. Görüşmelerde alanın kullanımı ve gerçekleştirilen aktiviteler, alanın özellikleri ve çekiciliği ve yer kimliği konuları irdelenmiştir. Görüşmeye katılanlar alanın kullanıcıları arasından rastgele seçilmiş kişilerdir. Görüşülen kişiler Eminönü, Galata köprüsü, deniz manzarası ve feribotları ve sandalları seyredebilme, martıların seslerini dinleme ve bölgenin tarihi anlamını hissedebilme, farklı kültürlerden insanlarla karşılaşma imkanı, alanın olumlu öğeleri olarak ifade ederken simit satan seyyar satıcılarının alana hayat ve anlam kazandırdıklarını belirtmişlerdir.

Kullanıcılar genellikle alanın kalabalık olmasını, eski ve harabe binaların bulunmasını ve alanın park yeri olarak tahsis edilmesini, satıcıların zaman zaman engellenmesini, alanın geceleri güvensiz bir ortam olmasını olumsuz özellikler olarak belirtmiş̧lerdir. Eskiden beri bu bölgede yaşayan bir kullanıcının ise bölgenin sosyo-demografik yapısında büyük bir değişim olduğunu vurgulaması dikkat çekici olmuştur.

Kullanıcıların çoğu deniz ulaşımı için burada olduklarından, alanın bir ulaşım noktası olarak kullanıldığı anlaşılmaktadır. Kullanım yoğunluğu özellikle sabah ve akşam saatlerinde artmaktadır. İkinci en yaygın aktivite hafta içi ve hafta sonu gerçekleşen isteğe bağlı ve sosyal aktivitelerdir. Alanda gerçekleşen ekonomik aktiviteler çoğunlukla balık pazarı, balık lokantası, kiosk da gerçekleşen alışveriş ve yeme-içme ile sokak satıcılarından yapılan alışverişlerdir. 
İsteğe bağlı yapılan aktiviteler ve sosyal aktiviteler arasında manzara seyretmek, balık tutmak, oturmak ve birlikte vakit geçirmek sayılabilir.

Ancak bu kullanımlar için alanın sınırlı olanaklar sunduğu ve alanın büyük bölümünün otopark tarafından işgal altında bulunduğu söylenebilir.

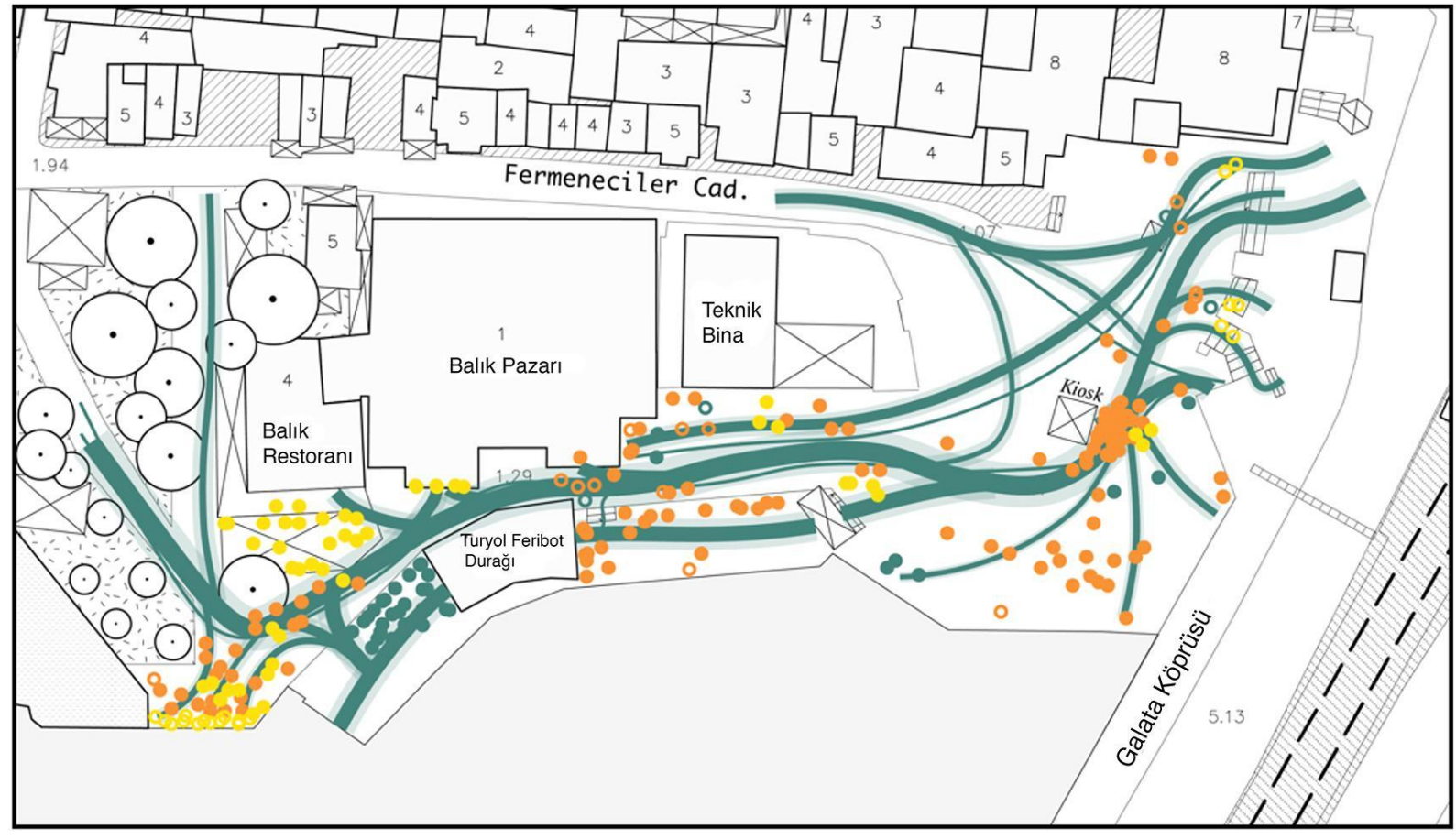

Zorunlu Aktiviteler

IIsteğe Bağlı Aktiviteler

Sosyal Aktiviteler

Şekil 10. Zorunlu, İsteğe Bağlı ve Sosyal Aktivitelerin Dağılımı

Kullanıcılarca olumlu özellikler "güzel”, "sahil”, “manzara”, "deniz”, "feribot” gibi kelimelerle, olumsuz özellikler "kalabalık", "eski binalar", "arabalar", "kirlilik" kelimeleriyle ifade edilmektedir. Alanın oluşturduğu kimliği tanımlayabilmek için görüşmelerin anahtar kelimeleri sentezlenmiş ve üç temel kimlik öğesi tanımlanmıştır (Tablo 1). Çoğunlukla güneşin doğuşunu veya gün batımını seyretmek, Eminönü, Galata köprüsü ve Haliç manzarasının tadını çıkarmak olarak tanımlanan kimlik ilk sırada yer almaktadır. Tanımlanan ikinci kimlik öğesi mekanın sosyal atmosferi ile ilgili olup sosyal etkinlikler için bu alanı ziyaret eden kullanıcılar tarafından vurgulanmıştır. Üçüncü kimlik öğesi ise yerel balıkçılık kültürünün deneyimlenmesidir. 
Vurgulanan tüm kimlik öğeleri alanın kamusal mekan olarak kullanılma potansiyelinin yüksek olduğunu ortaya koymaktadır. Ancak gözlem ve görüşmeler alanın deniz ve manzara ile ilişki kurmak, sosyal atmosferi canlandırmak ve balıkçılık kültürünü deneyimlemek için yeterli altyapı sunmadığını ortaya koymaktadır.

Tablo 1. Kamusal Yaşam ve Mekan ilişkisi

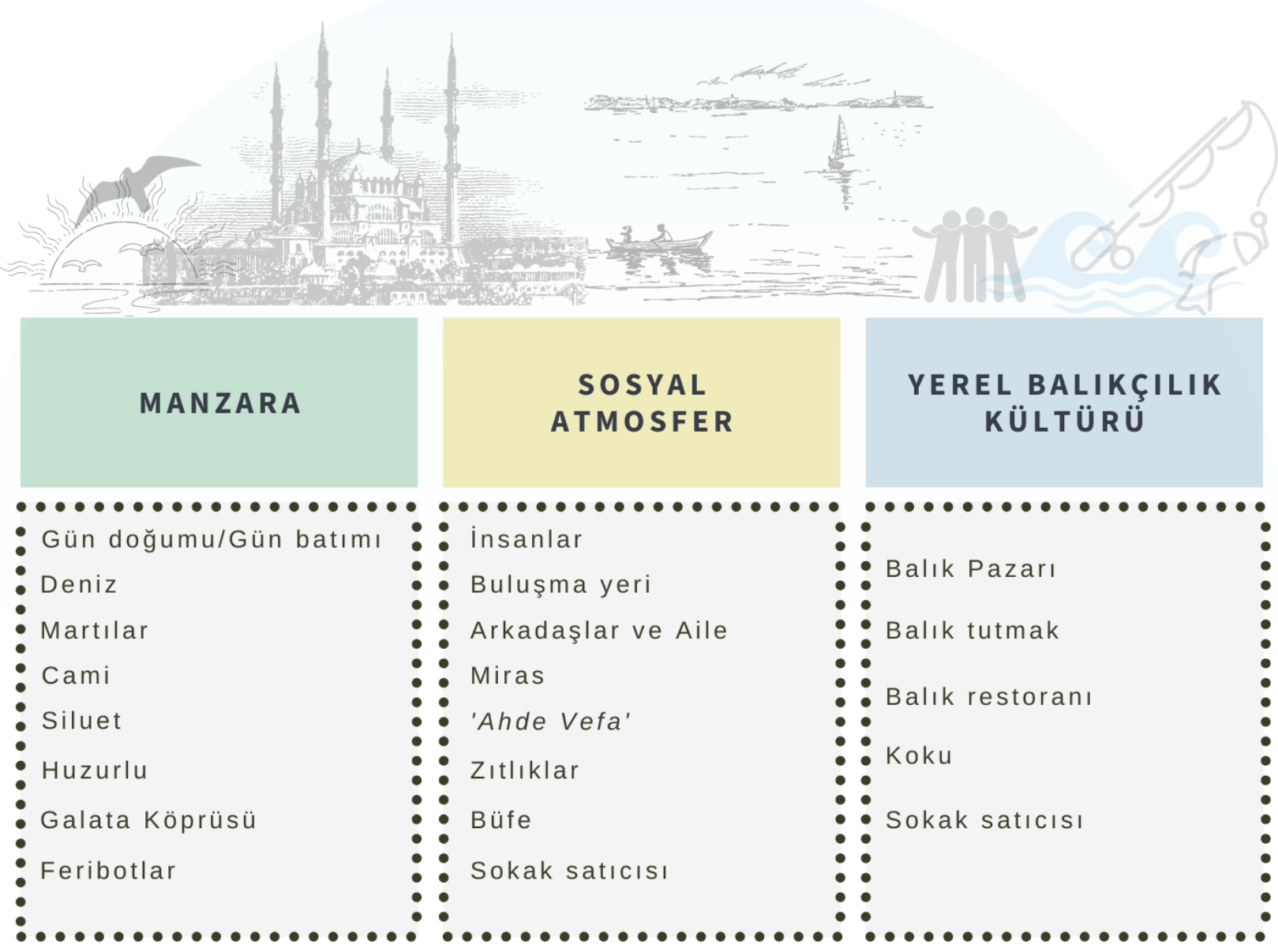

\section{SONUÇ VE DEĞERLENDİRME:}

Bir kentin merkezinde bulunan kamusal alan, merkezi konumu ve belirli işlevsel ve mekânsal özellikleri nedeniyle, kent sakinlerinin ihtiyaçlarını karşılamak ve sosyal etkileşimleri kolaylaştırmakta büyük rol oynar. Toplumsal yaşamın temelinde etkileşimler bulunur. Kamusal alandaki fiziksel özellikleri ise toplumun yaşam kalitesinde etkili olur. Gehl'in (1987) iyi düzenlenmiş bir kentsel açık alanda isteğe bağlı ve sosyal aktivitelerin arttığını ortaya koymaktadır.

Tarihi miras ve kültürel varlıklar ise kentin kimliğini oluşturur ve kentin canlılığına büyük ölçüde katkıda bulunur. Karaköy, hem Tarihsel geçmişi hem de morfolojik özellikleriyle İstanbul'un en önemli bölgelerinden biridir. Bugün yoğun bir şekilde kullanılan ve kentsel açık alan olarak potansiyel vadeden Galata Köprüsünün Karaköy ayağında yer alan çalışma alanı mekansal düzeni ile kamusal yaşamı desteklememektedir. Güçlü kimliği, aktif kullanımı ve erişilebilirliği yüksek alanın kentsel açık alan olarak sisteme katılması için tedbirler alınması ve çaba gösterilmesi 
gerektiği açıktır. İstanbul'un tarihi ve merkezi konumunda bulunan alanın, kültürel kimliğini koruması İstanbul için büyük öneme sahiptir.

Yapılan değerlendirmelerde bölgenin mekânsal kalitesinin düşük olduğu ortaya çıkmıştır. Ulaşım ve erişim olanakları, sıklık ve çeşitlilik açısından yeterli düzeydedir. Öte yandan alandaki oturma ve dinlenme alanları, yaya yolları, alanın otopark olarak da kullanılması ile kesintiye uğramakta ve konfor düzeyini düşürmektedir. Gölge alanların olmayışı, bitkilendirme, bakım ve temizlikte eksiklikler saptanmıştır. Gündüz yaşayan, gece dükkanların kapanması ile birlikte tenhalaşan bu alan, gece saatlerinde güvensiz olarak algılanmaktadır.

Kamusal alan olarak potansiyeli yüksek olan bu alanın düzenlenmesi ve kamusal yaşama kazandırılması, yerel balık kültürünün korunması, kamusal yaşamın bir parçası olan seyyar satıcıların da bu düzenlemede unutulmaması, alanın çöküntü bölgesi görünümünden kurtarılması ve yapıların onarılması, sahilde yaya kullanımını kesintiye uğratan otoparkın kaldırılması ve sosyal etkileşimi artıran düzenlemelerin yapılması Karaköyde yaşam kalitesinin yükseltecek bu kayıp alanı İstanbul'a kazandırılacaktır.

\section{Etik Standart ile Uyumluluk}

Çıkar Çatışması: Yazarlar herhangi bir çıkar çatışmasının olmadığını beyan eder.

Etik Kurul İzni: Bu çalışma için etik kurul iznine gerek yoktur.

Finansal Destek: Yoktur

\section{Teşekkür:}

Bu çalışma İstanbul Teknik Üniversitesi, Fen Bilimleri Enstitüsü, 'Kentsel Açık Alanlarda Çevresel Değerlendirilme' dersi kapsamında gerçekleştirilmiştir. Çalışmaya Erasmus öğrencileri Hanna Wahlberg ve Nicole Svensson de katkıda bulunmuşlardır.

\section{KAYNAKÇA:}

AKIN, N. (2011), Galata ve Pera, Literatür Yayıncılık, İstanbul.

ASLAN, Ş. (2011). Birleştiren ve Ayrıştıran İşlevleriyle İstanbul'da Boğaz Köprüler'nin Toplumsal Dili. İstanbul Üniversitesi Siyasal Bilgiler Fakültesi Dergisi , 0 (44), Erişim: https://dergipark.org.tr/tr/pub/iusiyasal/issue/594/5981.

APPLEYARD D., GERSON S.M., LINTELL M. (1981). Livable Streets, University of California Press.

BOURDIEU, P. (1984). Distinction: A Social Critique of the Judgment of Taste, Routledge and Kegan Paul, London.

FREELY, J. (2005). John Freely İstanbul'. Watson H. (Der.), Ofset Yapımevi, 178-180.

GEHL, J. (1987). Life Between Buildings: Using Public Space Washington-Covelo-London: Island Press.

GEHL, J. ve SVARRE, B. (2013). How To Study Public Life? Washington, DC: Island Press.

GEHL ARCHITECTS. Urban Quality Consultants. Gl. Kongevej 1, 4.tv . 1610 Copenhagen V. Denmark.

Erişim:https://gehlpeople.com/wp-content/uploads/2020/03/TWELVE-QUALITY-CRITERIA.pdf, 18.02.2020. 
HAUGE, C. (2004). Planning and Place Identity. Hague, C. ve Jenkins, P. (Der.), Place Identity, Participation and Planning. London: Routledge, 3-17.

JACOBS, J. (1961). The Death and Life of Great American Cities. New York: Random House.

HÜRRIYET (2 Aralık 2015). Karaköy Balık Pazarı Yeniden Açıldı. Hürriyet Gazetesi. Erişim: 17 Kasım 2019, http://www.hurriyet.com.tr/gundem/karakoy-balik-pazari-yeniden-acildi-40009411.

LEFEBVRE, H. (1971). Everyday Life in the Modern World, (S. Rabinovitch, Çev.). NY: Harper \& Row Publishers.

LEFEBVRE, H. (1991). The Production of Space. Blackwell, Cambridge.

LUTZONI, L. (2016). 'In-formalised urban space design. Rethinking the relationship between formal and informal', City, Territory and Architecture, volume 3, Article number: 20.

LILJA, E. (1995). İnsan vizyonu ve toplum planlaması. Nordic Topluluk Planlama Enstitüsü, Rapor 1995: 1, Stockholm.

LYNCH, K. (1960). The Image of the City. MIT Press, Cambridge.

Projects for Public Spaces. (PPS) (2008). 'JAN GEHL'. https://www.pps.org/article/jgehl [2019-11-27].

SENNETT, R. (1999). Gözün Vicdanı: Kentin Tasarımı ve Toplumsal Yaşam. Ayrıntı Yayınları, İstanbul.

SIMMEL, G. (1950). Metropolis and the Mental Life. Free Press, New York.

SUHER, H., OCAKÇI, M., KARABAY AYATAÇ, H., ERTEKIN, Ö. (2004) An Indicator of Sustainable Development: Urban Identity, ITÜ AZ Dergisi (2004-2), Vol. 1, No 2, 26-42: s 27.

TEKELİ, İ. (1996). Modernleşme Sürecinde Osmanlı Kentleri; Dumont, P. ve Georgeon, F. (Der.). Tarih Vakfı Yurt Yayınları, İstanbul. 